\title{
Efektivitas Model Pembelajaran Problem Solving dan Problem Based Learning (PBL) Ditinjau dari Kemampuan Berpikir Kreatif Matematis Siswa Kelas 5 Sekolah Dasar
}

\author{
Wahyu Indra Dewi, Nyoto Harjono ${ }^{2}$ \\ 1,2 Program Studi Pendidikan Guru Sekolah Dasar, Fakultas Keguruan Ilmu Pendidikan, Universitas Kristen Satya Wacana \\ Jl. Diponegoro, No. 52-60, Jawa Tengah, Indonesia \\ 292017146@student.uksw.edu
}

\begin{abstract}
The purpose of this study is to find out the effectiveness of Problem Solving (PS) and Problem Based Learning (PBL) learning models in improving the mathematical creative thinking skills of grade 5 students of SD Negeri Bringin 01. Data collection techniques are by observing and testing the effectiveness of ps and PBL models. Data analysis techniques are carried out through normality tests and homogeneity tests have met normal and homogeneous requirements, so it can be done lanju test with $t$ test, while for model effectiveness tests are conducted through $\mathrm{T}$ tests. $\mathrm{T}$ test results prove that there is a difference in effectiveness between Ps and PBL models. Judging from the difference in scoring through the same test, posttest on experiment 1 scored PS 59.9 and PBL 91.2; while the posttest results in experiment II averaged a PS score of 58.8 while PBL 92. When viewed from the achievement of the score, it is proven that PBL is more effective because the score is higher than PS, which is the difference of 32.25 . Based on this data, it can be concluded that there are differences in mathematical creative thinking skills from both test results in experimental class 1 and experiment II. It is also proven that pbl models are more effective in improving mathematical critical thinking skills compared to PS models
\end{abstract} Keywords: Problem Based Learning, Problem Solving, creative thinking skills, Elementary School

\begin{abstract}
Abstrak
Tujuan penelitian ini adalah untuk mengetahui efektivitas model pembelajaran Problem Solving (PS) dan Problem Based Learning (PBL) dalam meningkatkan kemampuan berpikir kreatif matematis siswa kelas 5 SD Negeri Bringin 01. Teknik pengumpulan data yaitu dengan obeservasi dan uji tes efektivitas terhadap model PS maupun PBL. Teknik analisis data dilakukan melalui uji normalitas dan uji homogenitas telah memenuhi syarat normal dan homogen, maka bisa dilakukan uji lanju dengan uji t, sedangkan untuk uji efektivitas model dilakukan melalui uji T. Hasil uji T membuktikan bahwa terdapat perbedaan efektivitas antara model PS dengan PBL. Dilihat dari selisih perolehan skor melalui tes yang sama, posttest pada eksperimen 1 perolehan skor PS 59,9 dan PBL 91,2; sedangkan hasil posttest pada eksperimen II rata-rata skor PS 58,8 sementara PBL 92. Bila dilihat dari pencapaian skor, terbukti bahwa PBL lebih efektif karena perolehan skor lebih tinggi dari PS, yakni selisih 32,25. Berdasarkan data ini dapat disimpulkan bahwa terdapat perbedaan kemampuan berpikir kreatif matematis baik dari hasil tes pada kelas eksperimen 1 maupun eksperimen II. Terbukti pula bahwa model PBL lebih efektif dalam meningkatkan kemampuan berpikir kritis matematis dibandingkan dengan model PS.
\end{abstract}

Kata kunci: Problem Based Learning, Problem Solving, berpikir kreatif, Sekolah Dasar

Copyright (c) 2021 Wahyu Indra Dewi, Nyoto Harjono

Corresponding author: Wahyu Indra Dewi

Email Address: 292017146@ student.uksw.edu (Jl. Diponegoro, No. 52-60, Jawa Tengah, Indonesia)

Received 24 July 2021, Accepted 10 August 2021, Published 15 August 2021

\section{PENDAHULUAN}

Menimba ilmu di sekolah dilakukan dengan pembelajaran. Pembelajaran adalah suatu kegiatan membelajarkan siswa yang bertujuan agar siswa dapat mengetahui segala sesuatu yang belum diketahuinya dan agar terjadi perubahan tingkah laku kearah yang positif. Pembelajaran dilakukan oleh dua subjek yaitu guru dan siswa. Kedua subjek tersebut saling berkaitan satu sama lain. Tugas seorang guru adalah mendidik dan mengajar siswa agar terjadi perubahan tingkah laku kearah yang positif, sedangkan tugas seorang siswa adalah belajar untuk dapat memperoleh prestasi yang baik. Untuk dapat memperoleh prestasi yang baik, siswa dituntut untuk memahami materi pelajaran yang diajarkan guru. 
Tetapi tidak semua yang diajarkan dalam materi pelajaran dapat diserap oleh semua siswa. Hal itu disebabkan oleh berbagai hal, salah satunya adalah kurang tepatnya guru dalam memilih model pembelajaran. Menurut direktorat jenderal pendidikan dasar dan menengah tahun 2017, model pembelajaran merupakan kerangka konseptual yang melukiskan prosedur yang sistematis dalam mengorganisasikan pengalaman belajar. Disisi lain, guru masih mengajar dengan menggunakan model pembelajaran yang konvensional.

Seperti diketahui dunia pendidikan sekarang ini telah mengalami kemajuan yang cepat. bukti kemajuannya yaitu dengan ditemukan adanya berbagai macam model-model pembelajaran yang inovatif. Dengan demikian dapat dikatakan bahwa Model pembelajaran yaitu suatu pola yang digunakan untuk penyusunan kurikulum, mengatur materi dan memberi arahan maupun pandangan kepada guru di kelas.

Model pembelajaran dalam kurikulum 2013 diharapkan dapat membentuk kompetensi yang memiliki kemampuan berpikir serta tindakan yang produktif dan aktif (Rouf \& Lufita, 2018). Model pembelajaran adalah kerangka konseptual yang melukiskan prosedur sistematis dalam mengorganisasikan sistem belajar untuk mencapai tujuan belajar tertentu dan berfungsi sebagai pedoman bagi perancang pembelajaran dan para pengajar dalam merencanakan dan melaksanakan aktivitas pembelajaran(Saefuddin \& Berdiati, 2014). Dalam mencapai tujuan pembelajaran diperlukan adanya suatu pembelajaran yang lebih bermakna bagi siswa.

Dalam memecahkan masalah matematika terdapat ketentuan dalam menyelesaikannya. Menurut Wahyuningsih, ada lima tujuan mata pelajaran matematika dalam standar isi. Salah satu dari lima tujuan tersebut yakni agar siswa mampu memecahkan masalah matematika yang meliputi kemampuan memahami masalah, merancang model matematika, menyelesaikan model dan menafsirkan solusi yang diperoleh. Penyelesaian pemecahan masalah matematika dapat juga dilakukan dengan cara menuliskan permasalahan yang ada, hal yang ditanyakan, dan apa saja yang dapat membantu dalam memperoleh penyelesaiannya (Wahyuningsih et al., 2010).

Berdasarkan penjelasan tersebut kegiatan pembelajaran perlu dilakukan dengan model pembelajaran yang dapat menambah semangat siswa untuk terlibat aktif dalam pembelajaran sehingga siswa dapat meningkatkan kemampuan berpikir kreatif khususnya dalam belajar Matematika.

Mengingat pentingnya matematika dalam kehidupan, maka matematika perlu dipahami dan dikuasai oleh semua masyarakat terutama siswa sekolah dasar. Kerap terjadi pada jenjang pendidikan dasar dan menengah adanya permasalahan yang berkaitan dengan kurangnya pengusaan materi. Dan apa penyebab sehingga siswa kurang tertarik dalam belajar matematika. Kesulitan dalam belajar matematika ini bersumber dari diri peserta didik akan tetapi bisa juga bersumber dari luar diri peserta didik. Misalnya, cara penyajian pelajaran yang dilakukan oleh guru yang kurang menarik sehingga peserta didik kurang beminat dalam belajar matematika.

Dalam pelaksanaan kegiatan pembelajaran tidak sedikit tenaga kependidikan kurang memperhatikan model pembelajaran yang dapat memberikan dampak baik bagi siswa. Salah satu 
komponen yang menekankan siswa pada pengaruh pembelajaran ialah dengan penerapan model pembelajaran yang relevan dengan kajian untuk materi yang akan diajarkan.

Guru sebaiknya memiliki kompetensi yang baik untuk mengembangkan kemampuan siswanya, walaupun dalam realita implementasinya sangat kurang. Hal ini dapat dilihat dari kurangnya kreasi maupun inivasi yang dilakukan sebagian besar guru saat ini, sehingga yang digunakan hanyalah pembelajaran konvensional, selain itu materi pembelajaran yang digunakan oleh guru hanya bersumber dari buku tema (pegangan guru dan siswa) saja tanpa adanya sumber tambahan lain. Guna menyikapi masalah yang telah disampaikan, maka guru hendaknya bisa membuat proses belajar mengajar yang lebih kreatif, dan bisa merubah pembelajaran kovensional menjadi pembelajaran yang lebih menyenangkan. Perubahan tersebut bisa dengan melakukan perubahan pada strategi, model atau metode pembelajaran dengan menjadikan siswa sebagai pusat pembelajaran, sehingga dapat meningkatkan kreativitas siswa.

Berpikir kreatif adalah sebuah kemampuan yang dimiliki oleh seseorang untuk berpikir secara terus-menerus dan konsisten dalam menghasilkan segala sesuatu yang kreatif. Pada proses berpikir kreatif tidak harus selalu membuat sebuah konsep yang benar-benar baru. Kemampuan berpikir dipandang sebagai kemampuan seseorang dalam menyelesaikan suatu masalah dengan menggunakan nalarnya. Kemampuan berpikir dalam matematika lebih ditekankan pada prosesnya, yakni proses berpikir dasar, kritis, serta berpikir kreatif. Oleh karena itu, kemampuan berpikir dalam matematika lebih tepat diistilahkan sebagai kemampuan berpikir dasar, kemampuan berpikir kritis, serta kemampuan berpikir kreatif. Ketika kemampuan berpikir kreatif berkembang maka akan melahirkan gagasan (ide), menemukan hubungan yang saling berkaitan, membuat dan melakukan imajinasi, serta mempunyai banyak perspektif terhadap suatu hal. Siswa yang memiliki kemampuan berpikir kreatif tinggi cenderung akan merasa tertantang dan tertarik untuk menyelesaikan berbagai masalah dalam belajar.

Berpikir kreatif siswa pada pelajaran Matematika dapat ditingkatkan melalui pembelajaran yang menarik dengan menggunakan model pembelajaran yang tepat sehingga siswa memiliki rasa ingin tahu yang besar. Pembelajaran Matematika yang dilaksanakan dengan menggunakan model pembelajaran PS dan PBL dapat membantu peserta didik dalam menyelesaikan permasalahan matematika dengan berbagai cara yang kreatif.

Shella Malisa, Iriani bakti dan Rila Iriani, melakukan penelitin tentang Model pembelajaran PS untuk meningkatkan hasil belajar dan kemampuan berpikir kreatif siswa. Penelitian menunjukkan penerapan model pembelajaran menggunakan model PS mengalami peningkatan. Hasil belajar kognitif siswa mengalami peningkatan sebesar 8,12\%, afektif dan psikomorik siswa mengalami peningkatan dengan kategori baik dan terampil. Kemampuan berpikir kreatif siswa pada aspek fluency pada siklus I sebesar 59,25\% dan pada siklus 2 menjadi 77,42\%, flexibility pada siklus I hanya 37,25\% dan pada siklus II menjadi 55,03\% serta elaboration pada siklus I hanya 39,75\% dan pada siklus II menjadi $69,75 \%$ (Malisa et al., 2018). 
Dian Kristiana, Wardan suyanto, melakukan penelitian tentang Implementasi Heuristik PS dalam Menyelesaikan Soal Cerita untuk Meningkatkan Presatasi dan Sikap Matematika. Penelitian menunjukkan bahwa prestasi belajar dan sikap siswa terhadap matematika mengalami peningkatan setelah dilaksanakan tindakan melalui neuritik Problem Solving dalam soal cerita matematika. Tes prestasi belajar sebelum tindakan adalah $59,5 \%$, kemudian meningkat $72,9 \%$ pada siklus 1 dan meningkat mendi $91,8 \%$ pada siklus 2 (Kristiana \& Suyanto, 2013).

Menurut Wena (2012) PS ialah suatu proses untuk menemukan kombinasi dari sejumlah aturan yang dapat diterapkan dalam upaya mengatasi situasi yang baru. Berbeda dengan Wena, Mulyaningsih menyatakan bahwa PS merupakan kemampuan memproses imformasi untuk membuat keputusan dalam memecahkan masalah (Mulyaningsih et al., 2013). Kemampuan setiap siswa dalam mengidentifikasi dan pemecahan masalah berbeda-beda.

Berdasarkan pendapat di atas dapat disimplkan bahwa PS merupakan kemampuan siswa dalam mengidentifikasi dan memecahkan masalah dalam upaya mengatasi situasi baru.

Putra dengan penelitiannya tentang "Meningkatkan kemampuan Berpikir Kreatif Siswa dengan menggunakan Pembelajaran Berbasis Masalah". Hasil penelitiannya menyatakan dampak positif terhadap peningkatan berpikir kreatif siswa setelah menggunakan pembelajaran PBL (Putra et al., 2012).

Cahyaningsih melakukan penelitian tentang "Pengaruh penggunaan Model PBL terhadap Karakter Kreatif dan Berpikir Kritis Dalam Pembelajaran Matematika" ada pengaruh yang signifikan dari model PBL terhadap peningkatan karakter kreatif dan kemampuan berpikir kritis matematika siswa setelah mengikuti pembelajaran dengan model PBL (Cahyaningsih \& Ghufron, 2016).

Pembelajaran PS dan PBL memang tidak sama, namun mempunyai satu sisi persamaan, yaitu pembelajaran dititikberatkan pada aktivitas siswa untuk pemecahan masalah. Mencermati berbagai potensi kedua model pembelajaran menunjukkan keampuhan kedua model secara empirik, hal ini membingungkan guru dalam memilih model pembelajaran yang akan digunakan dalam pembelajaran karena ke dua model tersebut sama-sama mempunyai potensi dapat diterapkan dalam membelajarkan konsep-konsep matematika; oleh karena itu perlu dibuktikan model mana yang lebih ampuh untuk diterapkan dalam pembelajaran matematika.

Berpijak dari hasil penelitian sebelumnya terhadap keefektifan penerapan model pembelajaran PS dan PBL sehingga menimbulkan keragu-raguan bagi peneliti. Berhubungan dengan hal tersebut peneliti bermasud untuk ikut serta dalam memberikan partisipasi membuktikan kedua model tersebut dengan melalui kegiatan penelitian yang berjudul "Efektivitas Model Pembelajaran PS dan PBL ditinjau dari Kemampuan Berpikir Kreatif Matematis siswa kelas V Sekolah Dasar" penelitiakan membendingkan dua model pembelajaran dalam mengajar, hasil penelitian ini nantinya akan menjadi acuan bagi guru untuk dapat memilih model yang relevan diterapkan di lapangan, khususnya dalam membelajarkan konsep-konsep matematika.

Dalam penelitian ini siswa dituntut mampu berpikir Kreatif, kritis dan logis dalam menemukan solusi dari permasalahan yang diberikan. Salah satu cara dalam menyajikan pelajaran yaitu dengan 
meminta siswa untuk mencari maupun menemukan cara penyelesaian permasalahan. Dalam Model PS dan $P B L$ kedua model tersebut mengutamakan penyajian pembelajaran agar peserta didik memecahkan masalah dan mencari solusi dalam menyelesaikan masalah.

\section{METODE PENELITIAN}

\section{Jenis Penelitian}

Jenis penelitian ini adalah penelitian eksperimen menggunakan metode eksperimen kuasi. Counterbalanced design atau desain Berimbang dapat melihat perbedaan efektivas model pembelajaran PS dan model pembelajaran PBL setelah diberikan perlakukan.

Tabel 1. Desain penelitian Counterbalanced Design

\begin{tabular}{|c|c|c|c|c|}
\hline Group & Perlakuan & Posttest & Perlakuan & Posttest \\
\hline Eksperimen1 & $\mathrm{X}_{1}$ & $\mathrm{O}_{1}$ & $\mathrm{X}_{2}$ & $\mathrm{O}_{2}$ \\
\hline Eksperimen 2 & $\mathrm{X}_{2}$ & $\mathrm{O}_{2}$ & $\mathrm{X}_{1}$ & $\mathrm{O}_{1}$ \\
\hline
\end{tabular}

\section{Keterangan:}

$\mathrm{X}_{1}$ : Pembelajaran menggunakan model Problem Solving

$\mathrm{X}_{2}$ : Pembelajaran menggunakan model Broblem Based Learning (PBL)

$\mathrm{O}_{1}$ : Hasil Test kelas eksperimen 1 menggunakan model Problem Solving

$\mathrm{O}_{2}$ : Hasil Test kelas eksperimen 2 menggunakan model Broblem Based Learning (PBL)

Dalam penelitian ini populasi yang diambil adalah seluruh kelas 5 Gugus Gajah Mada yang terletak di wilayah Kecamatan Bringin, Kabupaten Semarang. Sampel yang dipilih dalam penelitian ini terdapat pada Gugus Gajah Mada yaitu SD Negeri Bringin 01 yang berjumlah 46 siswa dengan memiliki 2 kelas paralel yakni kelas 5A berjumlah 22 siswa dan 5B berjumlah 24 siswa. Dalam penelitian ini membutuhkan dua kelas yaitu kelas Eksperimen 1 dan kelas Eksperimen 2, dengan demikian peneliti memilih kelas A sebagai kelas Eksperimen 1 dan kelas B sebagai kelas Eksperimen 2.

\section{Teknik dan Instrumen Pengumpulan Data}

Teknik pengambilan sampel dalam penelitian ini diperoleh melalui teknik probability sampling dengan jenis cluster sampling (area sampling). Menurut Sugiyono (Sugiyono, 2018), teknik ini memberikan peluang yang sama bagi anggota populasi untuk dipilih menjadi anggota sampel. Cluster sampling digunakan untuk pengambilan sampel yang berada pada populasi yang berkelompok. Pengambilan sampel didasarkan pada pertimbangan bahwa setiap cluster memiliki siswa dengan karakteristik yang relatif sama, sehingga dapat diambil perwakilan dari masing-masing cluster untuk diteliti. Data yang diperoleh dalam penelitian ini berupa data terhadap keterampilan berpikir kreatif matematika kelas V SD. teknik pengumpulan data yang digunakan yaitu soal Tes dan observasi.

\section{Teknik Analisis Data}

Analisis data dilakukan untuk hasil data yang berupa proses dan hasil. Proses yang dimaksud adalah pelaksanaan pembelajaran untuk kedua model yang digunakan. Analisis hasil digunakan untuk 
menganalisis hasil tes yang digunakan untuk melihat efektivitas masing-masing model Keefektifan model PS dan PBL terhadap kemampuan berpikir kreatif siswa dilakukan uji beda rata-rata dengan menggunakan Independent Sample T-Test. Penggunaan data dalam uji beda rata-rata adalah data sesudah perlakuan atau posttest. Kemudian setelah memperoleh hasil dilakukan uji hipotesis yang memiliki kriteria keputusan H0 diterima apabila probabilitas > 0,05 dan Ha diterima jika probabilitas < 0,05. Setelah mengetahui keefektifan dari kedua model terhadap kemampuan berpikir kritis siswa, kemudian dilakukan uji N-Gain untuk mengetahui kekuatan efektivitas dari kedua kelas eksperimen. Berikut ini adalah hasil uji Effect Size dengan hasil perhitungan pada tabel 2 berikut ini:

Tabel 2. Hasil Perhitungan Uji Effect Size

\begin{tabular}{|l|l|}
\hline \multicolumn{1}{|c|}{ Uji Efect Size } & \multicolumn{1}{c|}{ Uji Efect Size } \\
\hline Effect Size & 0,099 \\
\hline Kategori & Kecil \\
\hline
\end{tabular}

Hasil dari perhitungan effect size sebesar 0,099 dan masuk kedalam kategori kecil $(d=0,099)$. Disimpulkan bahwa dengan menggunakan metode PBL efektif dalam meningkatkan hasil belajar peserta didik.

\section{HASIL DAN DISKUSI}

Berdasarkan hasil analisis deskriptif diperoleh data komparasi hasil pengukuran posttest 1 dan posttest 2 kemampuan berpikir kreatif siswa yang disajikan sebagai berikut:

Tabel 3. Komparasi Hasil Pengukuran Kemampuan Berpikir Kreatif Siswa

\begin{tabular}{|c|c|c|c|}
\hline \multirow{2}{*}{ Pengukuran } & \multicolumn{2}{|c|}{ Rata-rata Skore (Mean) } & \multirow{2}{*}{ Selisih } \\
\cline { 2 - 3 } & Eksperimen 1 & Eksperimen 2 & \\
\hline PS & 59,9 & 58,8 & 1,1 \\
\hline PBL & 91,2 & 92,7 & 1,5 \\
\hline
\end{tabular}

Berdasarkan data komparasi rata-rata yang disajikan pada Tabel 2, rata-rata skor pretest antara kelompok eksperimen 1 yang diberikan perlakuan PS dan kelompok eksperimen 2 yang diberi perlakuan PBL terdapat selisih sekitar 1,1. Sedangkan untuk rata-rata skor posttest antara kedua kelompok eksperimen terdapat selisih sebesar 1,5. Berikut diagram komparasi data kedua kelompok disajikan dalam Gambar 1.

Berdasarkan informasi Gambar 1, dapat diketahui adanya peningkatan pada kelompok eksperimen 1 yang menerapkan PS maupun kelompok eksperimen 2 dengan model PBL. Dari hasil perolehan data penelitian selanjutnya dilaksanakan uji normalitas dan uji homogenitas sebagai uji persyaratan. Hasil uji normalitas dapat dilihat pada Tabel 4 sedangkan hasil uji homogenitas pada Tabel 5 dan 6. 


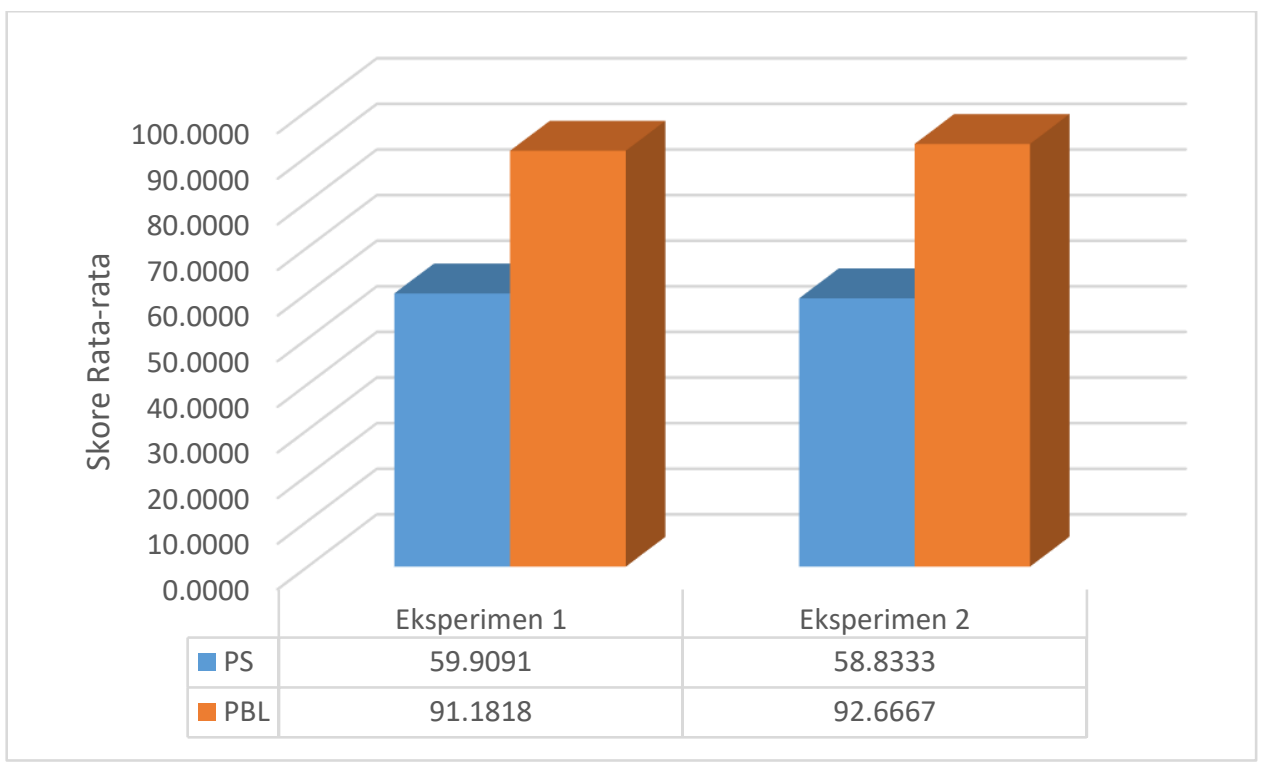

Gambar 1. Komparasi Data Kelompok Eksperimen

Tabel 4. Uji Normalitas Kelompok Eksperimen 1 dan Eksperimen 2 One-Sample Kolmogorov-Smirnov Test

\begin{tabular}{|ll|r|r|r|r|}
\hline & & \multicolumn{1}{|c|}{ PS_1 } & PBL_1 & \multicolumn{1}{c|}{ PS_2 } & PBL_2 \\
\hline $\mathrm{N}$ & & 22 & 22 & 24 & 24 \\
Normal Parameters & Mean & 59,9091 & 91,1818 & 58,8333 & 92,6667 \\
& Std. & 6,98235 & 5,98917 & 5,45070 & 5,60021 \\
& Deviation & & & & \\
Most Extreme & Absolute &, 177 &, 147 &, 126 &, 183 \\
Differences & Positive &, 177 &, 124 &, 092 &, 183 \\
Kolmogorov-Smirnov Z & Negative &,- 118 &,- 147 &,- 126 &,- 162 \\
Asymp. Sig. (2-tailed) & &, 828 &, 690 &, 619 &, 897 \\
\hline
\end{tabular}

a. Test distribution is Normal.

b. Calculated from data.

Hasil uji normalitas pretest dan posttest dari kedua kelas eksperimen. Teknik yang digunakan dalam uji normalitas adalah One-Sample Kolmogorov-Smirnov dapat dikatakan berdistribusi normal jika hasil signifikan $>0,05$.

1. Tingkat signifikasi nilai pretest kelompok eksperimen 1 adalah $0,499>0,05$, artinya nilai berdistribusi normal.

2. Tingkat signifikasi nilai posttest kelompok eksperimen 1 adalah $0,727>0,05$ artinya nilai berdistribusi normal.

3. Tingkat signifikasi nilai pretest kelompok eksperimen 2 adalah $0,838>0,05$, artinya nilai berdistribusi normal.

4. Tingkat signifikasi nilai pretest kelompok eksperimen 2 adalah $0,397>0,05$, artinya nilai berdistribusi normal.

Dari data di atas dapat diketahui perolehan hasil pretest dan posttest signifikan $>0,05$ maka disimpulkan bahwa data memiliki berdistribusi normal. 
Berdasarkan informasi Tabel 4 dan Tabel 5 diperoleh hasil uji homogenitas menggunakan metode Levene Statistic. Dengan memilih salah satu interprestasi statistik yang didasarkan pada rata-rata (Based on Mean). Pada Tabel menunjukkan hasil uji homogenitas sebelum diberi perlakuan memperoleh nilai signifikasi 0,946 dimana > 0,05 yang berarti kedua kelas sebelum diberi perlakuan memiliki varian yang sama atau homogen. Sedangkan pada Tabel 5 menunjukkan hasil uji homogenitas setelah diberi perlakuan memperoleh nilai signifikasi 0,390 dimana > 0,05 yang berarti kedua kelas sesudah diberi perlakuan memiliki varian yang berbeda atau homogen.

Tabel 5. Uji Homogenitas Sebelum Perlakuan

\section{Test of Homogeneity of Variances}

PS

\begin{tabular}{|c|c|c|c|}
\hline $\begin{array}{c}\text { Levene } \\
\text { Statistic }\end{array}$ & df1 & df2 & Sig. \\
\hline, 180 & 4 & 16 & $\mathbf{9 4 6}$ \\
\hline
\end{tabular}

Tabel 6. Uji Homogenitas Setelah Perlakuan

Test of Homogeneity of Variances PBL

\begin{tabular}{|c|c|c|c|}
\hline $\begin{array}{l}\text { Levene } \\
\text { Statistic }\end{array}$ & df1 & $\mathrm{df} 2$ & Sig. \\
\hline 1,153 & 5 & 11 & ,390 \\
\hline
\end{tabular}

Setelah melakukan uji persyaratan yang telah dilakukan dapat diketahui bahwa data distribusi normal dantidak homogen. Setelah itu dilakukan analisis uji T menggunakan independent sample T test. Uji $\mathrm{T}$ bertujuan untuk mengetahui ada tidaknya perbedaan efektivitas antara kedua kelompok eksperimen terhadap kemampuan berpikir kreatif siswa. Hasil analisis uji $\mathrm{T}$ disajikan dalam bentuk Tabel 6. Berdasarkan data Tabel 6, hasil uji T menggunakan independent sample $\mathrm{T}$ test menunjukkan hasil bahwa thitung sebesar 26,144 dengan signifikasi pada kolom Sig(2-tailed) sebesar 0,000. Perbedaan rata-rata dari kelompok mean diference sebesar 32,609. $\mathrm{T}_{\text {tabel }}$ yang diperoleh dari data di atas adalah 2,020 .

Tabel 7. Hasil Analisis Uji T dengan Independent Sample T-Test

\begin{tabular}{|c|c|c|c|c|c|c|c|c|c|c|}
\hline \multicolumn{11}{|c|}{ Independent Samples Test } \\
\hline & & \multicolumn{2}{|c|}{$\begin{array}{l}\text { Levene's } \\
\text { Test for } \\
\text { Equality of } \\
\text { Variances }\end{array}$} & \multicolumn{7}{|c|}{ t-test for Equality of Means } \\
\hline & & \multirow[t]{2}{*}{$\mathrm{F}$} & \multirow[t]{2}{*}{ Sig. } & \multirow[t]{2}{*}{$\mathrm{t}$} & \multirow[t]{2}{*}{$\mathrm{df}$} & \multirow[t]{2}{*}{$\begin{array}{l}\text { Sig. (2- } \\
\text { tailed) }\end{array}$} & \multirow[t]{2}{*}{$\begin{array}{c}\text { Mean } \\
\text { Differenc } \\
\mathrm{e}\end{array}$} & \multirow{2}{*}{$\begin{array}{l}\text { Std. } \\
\text { Error } \\
\text { Differ } \\
\text { ence }\end{array}$} & \multicolumn{2}{|c|}{$\begin{array}{l}\text { 95\% Confidence } \\
\text { Interval of the } \\
\text { Difference }\end{array}$} \\
\hline & & & & & & & & & Lower & Upper \\
\hline Skore & $\begin{array}{c}\text { Equal } \\
\text { variances } \\
\text { assumed }\end{array}$ & 012 & ,912 & 26,144 & 90 & ,000 & 32,609 & 1,247 & $-35,087$ & $-30,131$ \\
\hline
\end{tabular}




\begin{tabular}{|l|l|l|l|l|l|l|l|l|l|}
\hline $\begin{array}{l}\text { Equal } \\
\text { variances } \\
\text { not } \\
\text { assumed }\end{array}$ & & & 26,144 & 89,580 & $\mathbf{, 0 0 0}$ & 32,609 & 1,247 & $-35,087$ & $-30,131$ \\
\hline
\end{tabular}

Setelah melakukan analisis uji independent sample $\mathrm{T}$ test pada Tabel 7 , selanjutnya untuk uji hipotesis penelitian. Langkah-langkah dalam pengujian hipotesis bertujuan untuk menentukan apakah hipotesis diterima atau ditolak.

H0: Tidak terdapat perbedaan yang signifikan antara penggunaan model PS dan PBL terhadap kemampuan berpikir kreatif dalam mata pelajaran Matematika siswa kelas V.

Ha: Terdapat perbedaan yang signifikan antara penggunaan model PBL dan PS terhadap kemampuan berpikir kreatif dalam mata pelajaran Matematika siswa kelas V.

Kriteria pengambilan keputusan:

1. Menggunakan koefisien Sig. Dengan ketentuan:

a. Jika nilai sig. Hitung (probabilitas) $<0,05 \mathrm{H} 0$ ditolak

b. Jika nilai sig. Hitung (probabilitas) $\geq 0,05$ Ha diterima

2. Menggunakan koefisien t Hitung dengan ketentuan:

a. Jika koefisien $t$ Hitung $<\mathrm{t}$ tabel maka H0 ditolak

b. Jika koefisien $\mathrm{t}$ Hitung $>\mathrm{t}$ tabel maka Ha diterima

Sesuai dengan kriteria pengujian hipotesis, bahwa nilai signifikasinya menunjukkan 0,000 $<0,05$ sehingga H0 ditolak. Oleh sebab itu hasil uji hipotesis menyatakan terdapat perbedaan efektivitas model pembelajaran PBL dan PS terhadap kemampuan berpikir kreatif dalam mata pelajaran Matematika siswa kelas V.

Berdasarkan uji beda rata-rata posttest dapat dilihat bahwa kemampuan berpikir kreatif matematika siswa kelompok eksperimen 1 lebih tinggi dibandingkan dengan kelompok eksperimen 2. Hal ini menunjukkan bahwa perlakuan yang dilakukan pada kelompok eksperimen 1 lebih efektif dibandingkan dengan perlakukan kelompok eksperimen 2. Uji normalitas Gain digunakan untuk mengetahui seberapa kuat keefektifan dari penerapan kedua model pembelajaran.

Untuk peningkatan skor rata-rata pretest dan posttest digunakan rumus gain rata-rata ternormalisasi, yaitu perbandingan gain rata-rata aktual dengan gain rata-rata maksimum. Gain rata-rata aktual adalah selisih skor rata-rata antara posttest 1 dan 2. Rumus gain ternormalisasi tersebut sering juga disebut faktor g, atau faktor Hake (Wiyanto, 2008):

$$
\langle g\rangle=\frac{\left\langle\bar{S}_{\text {post }}\right\rangle-\left\langle\bar{S}_{\text {pre }}\right\rangle}{100 \%-\left\langle\bar{S}_{\text {pre }}\right\rangle}
$$

Keterangan:

$\mathrm{g}=$ faktor $\mathrm{g}$ (faktor Hake) atau nilai gain skor ternormalisasi. 
Tabel 7. N-Gain

\begin{tabular}{|c|l|l|}
\hline No & Kriteria & Keterangan Nilai Interval \\
\hline 1 & Tinggi & $\mathrm{g} \geq 0,7$ atau dinyatakan dalam persen $\mathrm{g} \geq 70$ \\
\hline 2 & Sedang & $0,3 \leq \mathrm{g}<0,7$ atau dinyatakan dalam persen $30 \leq \mathrm{g}<70$ \\
\hline 3 & Rendah & $\mathrm{g}<0,3$ atau dinyatakan dalam persen $\mathrm{g}<30$ \\
\hline
\end{tabular}

Hasil uji normalitas gain kelas eksperimen 1 menunjukkan bahwa rata-rata kelas eksperimen 1 mengalami peningkatan sebesar 0,71 yang berarti $\mathrm{N}$-Gain mengalami peningkatan kategori tinggi. Demikian juga hasil uji normalitas gain kelas eksperimen 2 memiliki rata-rata 0,71 yang berarti N-Gain juga mengalami peningkatan kategori tinggi.

Berdasarkan hasil penelitian, model pembelajaran PBL dan PS dapat meningkatkan kemampuan berpikir kreatif siswa. Keberhasilan penelitian ini didukung dengan meningkatnya hasil posttest $1 \mathrm{ke}$ posttest 2 sehingga dapat diketahui terdadapat perbedaan yang signifikan ketika sesudah dilakukan penerapan menggunakan model PBL dan sesudah dilakukan peneraran model PS. Dengan dilakukan analisis data menunjukkan hasil menggunakan model PBL lebih tinggi dibandingkan dengan menggunakan model PS.

Hasil output uji Independent Sample T-Test pada Tabel 7 diketahui bahwa nilai signifikasi 2tailed sebesar 0,000 yang artinya lebih kecil dari 0,05 maka Ho ditolak dan Ha diterima. Karena Ho ditolak dan Ha artinya terdapat perbedaan efektivitas antara model PBL dan PS terhadap kemampuan Berpikir Kreatif matematika peserta didik kelas 5 SD Negeri Bringin 01. Keberhasilan model PBL yang efektif meningkatkan kemampuan berpikir kreatif matematika peserta didik dipengaruhi oleh kegiatan pembelajaran yang dilaksanakan dengan mengorientasi peserta didik pada masalah hingga masalah tersebut dipecahkan. Pembiasaan pembelajaran dengan model tersebut dapat meningkatkan kemampuan berpikir kreatif matematika dengan efektif. Sejalan dengan Hung (dalam Astuti et al., 2018) yang menyatakan bahwa dengan mengharuskan peserta didik memecahkan masalah sebagai format utama instruksi dalam pembelajaran, PBL dapat meningkatkan kemampuan dan ketrampilan dalam menerapkan pengetahuan, memecahkan masalah, mempraktekkan pemikiran tingkat tinggi dirinya sendiri.

Hasil ini memperkuat penelitian yang dilakukan oleh Yusri (2018), yang menghasilkan bahwa diterapkannya model pembelajaran PBL dapat meningkatkan kemampuan pemecahan masalah peserta didik. Begitu juga penelitian yang dilakukan oleh Indarwati, Wahyudi, \& Ratu, (2014) menyatakan bahwa melalui penerapan model Problem Based Learning berpengaruh terhadap kemampuan pemecahan masalah pada peserta didik. Penelitian yang dilakukan oleh Ruchhaedi, Suryadi, dan Herman (2016), yang menghasilkan bahwa model pembelajaran PBL dapat meningkatkan kemampuan strategi heuristik pemecahan masalah matematis yang lebih baik. 


\section{KESIMPULAN}

Berdasarkan pembahasan yang telah diuraikan sebelumnya, maka dapat disimpulkan bahwa terdapat perbedaan kemampuan berpikir kreatif siswa dari kelas eksperimen 1 yang menggunakan model Problem Solving dan kelas eksperimen 2 menggunakan model Problem Based Learning (PBL). Kedua model tersebut dapat meningkatkan kemampuan berpikir kreatif matematis siswa SD Negeri Bringin 01 secara efektif sebesar 71,38\% untuk kelompok eksperimen 1, sedangkan tingkat efektivitas kelompok eksperimen sebesar 71,05, jadi kelompok eksperimen 2 yang menggunakan model pembelajaran PBL lebih efektif dari pada ekspreimen 1 yang mengunakan model pembelajaran PS.

\section{UCAPAN TERIMA KASIH}

Penulis mengucapkan terima kasih dan mengucap syukur kepada Allah SWT yang telah memberikan kelancaran kepada penulis dalam menyusun artikel ini. Saya ucapkan terima kasih yang sebesar bersarnya kepada kedua orang tua yang senantiasa mendoakan dan memberi motivasi kepada penulis dalam menyusun artikel ini hingga dapat terselesaikan. Kemudian penulis mengucapkan terima kasih kepada dosen pembimbing Drs. Nyoto Harjono, M.Pd. yang membimbing, mengarahkan, dan mengedit proses penyelesaian artikel. Tidak lupa penulis ucapkan terimakasih kepada teman-teman seperjuangan yang telah memberikan motivasi serta semangat yang tiada hentinya.

\section{REFERENSI}

Astuti, D. A. P., Slameto, \& Setyaningtyas, E. W. (2018). Pengaruh Penerapan Model Problem Solving Terhadap Kemampuan Pemecahan Masalah Siswa Kelas Iv Sd. Jurnal Didaktika Dwija Indria (SOLO), 6(3).

Cahyaningsih, U., \& Ghufron, A. (2016). Pengaruh Penggunaan Model Problem-Based Learning Terhadap Karakter Kreatif Dan Berpikir Kritis Dalam Pembelajaran Matematika. Jurnal Pendidikan Karakter, 1, 104-115. https://doi.org/10.21831/jpk.v0i1.10736

Indarwati, D., Wahyudi, W., \& Ratu, N. (2014). Peningkatan Kemampuan Pemecahan Masalah Matematika Melalui Penerapan Problem Based Learning Untuk Siswa Kelas V Sd. Satya Widya, 30(1), 17. https://doi.org/10.24246/j.sw.2014.v30.i1.p17-27

Kristiana, D., \& Suyanto, W. (2013). Implementasi Heuristic Problem Solving Dalam Menyelesaikan Soal Cerita Untuk Meningkatkan Prestasi Dan Sikap Matematika. Jurnal Prima Edukasia, 1(1), 17. https://doi.org/10.21831/jpe.v1i1.2313

Malisa, S., Bakti, I., \& Iriani, R. (2018). Model Pembelajaran Creative Problem Solving (Cps) Untuk Meningkatkan Hasil Belajar Dan Kemampuan Berpikir Kreatif Siswa. Vidya Karya, 33(1), 1. https://doi.org/10.20527/jvk.v33i1.5388

Mulyaningsih, R., Lasmawan, M., \& Sutama, M. (2013). Pengaruh Model Problem Solving Berbasis Budaya Lokal Terhadap Motivasi Berprestasi Dan Prestasi Belajar IPS. Jurnal Pendidikan Dasar Ganesha, 3(1), 121439.

Putra, T. T., Irwan, \& Vionanda, D. (2012). Meningkatkan Kemampuan Berpikir Kreatif Siswa dengan Pembelajaran Berbasis Masalah. Jurnal Pendidikan Matematika, 1(1), 22-26.

Rouf, A., \& Lufita, R. (2018). Peranan Guru dalam Implementasi Kurikulum 2013 di Madrasah 
Ibtidaiyah Negeri 1 Jombang. Sumbula, 3(2), 903-926.

Ruchaedi, D., Baehaki, I., \& Herman, T. (2016). Pengaruh Problem Based Learning (Pbl) Terhadap Kemampuan Heuristik Pemecahan Masalah Dan Sikap Matematis Siswa Sekolah Dasar. Jurnal Cakrawala Pendas, 2(2). https://doi.org/10.31949/jcp.v2i2.331

Saefuddin, A., \& Berdiati, I. (2014). Pembelajaran Efektif. PT Remaja Rosdakarya.

Sugiyono. (2018). Metode Penelitian Pendidikan. Alfabeta.

Wahyuningsih, E., Wardhani, S., \& Purnomo, S. S. (2010). Pembelajaran Kemampuan Pemecahan Masalah Matematika di SD (T. Widyantini \& Marfuah (eds.)). Kementerian Pendidikan Nasional Badan Pengembangan Sumber Daya Manusia Pendidikan dan Penjaminan Mutu Pendidikan.

Wena, M. (2012). Strategi Pembelajaran Inovatif Kontemporer: suatu tinjauan konseptual operasional. Bumi Aksara.

Wiyanto. (2008). Pengembangan Kemampuan Merancang dan Melaksanakan Kegiatan Laboratorium Fisika Berbasis Inkuiri Bagi Mahasiswa Calon Guru. PPs UPI Bandung.

Yusri, A. Y. (2018). Pengaruh Model Pembelajaran Problem Based Learning Terhadap Kemampuan Pemecahan Masalah Matematika Siswa Kelas VII di SMP Ngeri Pangkajene. Mosharafa, 7, 5162. 